\title{
Ouvidoria Itinerante - Secretaria de Estado da Saúde de São Paulo
}

\author{
Piccirillo, Carmen Lúcia Pádua; Silva, Luis Carlos Pereira da; \\ Ferreira, Patricia Camargo \\ Secretaria de Estado da Saúde de São Paulo - cpiccirillo@saude.sp.gov.br
}

Introdução ao assumir a Secretaria de Estado da Saúde, o médico infectologista David Emerson Uip junto com sua equipe, elaborou um cronograma de visitas multiprofissionais aos hospitais e serviços de saúde da rede estadual, com o intuito de identificar quais as questões mais urgentes a serem revolvidas. Essas visitas tem o objetivo de fortalecer a assistência à saúde, para isso é preciso ouvir não só o diretor do serviço, mas também a população. e o serviço mais indicado para realizar esse trabalho é a Ouvidoria, um serviço que possibilita a avaliação da qualidade do serviço prestado por quem o utiliza. Antecedendo a visita, foi programada a Ouvidoria Itinerante, com uma equipe preparada para acolher o usuário através da escuta qualificada. As informações colhidas são sistematizadas com a finalidade de subsidiar o trabalho do Secretário e a tomada de decisão. Justificativa Sendo a Ouvidoria um espaço estratégico e democrático de comunicação entre o cidadão e os gestores, entendemos como um serviço de fundamental importância para identificar as questões mais urgentes a serem resolvidas pelo Secretário de Saúde. Objetivos Colher, registrar e encaminhar as manifestações. Elaborar um relatório simples e de fácil visualização. Métodos - Descrição Sucinta a equipe da Ouvidoria Itinerante foi formada por profissionais do Projeto de Reestruturação do Setor de Ouvidoria do Estado da Saúde de São Paulo, preparados e capacitados, se organizaram junto com a Ouvidoria da Instituição a ser visitada para conversar com os usuários do serviço e saber qual a sua opinião com relação ao serviço prestado. Resultados: o projeto ainda está em andamento, mas foram realizadas 11 Ouvidorias Itinerantes, com um total de 1531 manifestações.

Piccirillo, Carmen Lúcia Pádua; Silva, Luis Carlos Pereira da; Ferreira, Patricia Camargo. Ouvidoria Itinerante - Secretaria de Estado da Saúde de São Paulo. In: Anais do Congresso Internacional de Humanidades \& Humanização em Saúde [= Blucher Medical Proceedings, num.2, vol.1]. São Paulo: Editora Blucher, 2014. ISSN 2357-7282

DOI 10.5151/medpro-cihhs-10390 